\title{
Sistem Pendukung Keputusan Penilaian Kinerja Guru Menggunakan Metode Simple Additive Weighting
}

\author{
Ali Fa'ul Mustofa ${ }^{1}$, Maryo Indra Majaruni ${ }^{2}$ \\ ${ }^{1}$ Sekolah Tinggi Teknologi Cahaya Surya Kediri \\ ${ }^{2}$ Sekolah Tinggi Teknologi Cahaya Surya Kediri \\ $\underline{\text { alifau169@gmail.com }}^{1}$, maryo@ cahayasurya.ac.id ${ }^{2}$
}

\begin{abstract}
Abstrak
Penilaian kinerja guru merupakan proses analisis untuk menghasilkan pengajaran yang lebih baik. Proses penilaian terhadap kinerja guru kelas di Sekolah Dasar Negeri Kampung Dalem 3, Sekolah Dasar Negeri Kampung Dalem 4 dan Sekolah Dasar Negeri Kampung Dalem 5 Kediri masih manual dan belum begitu detail (terperinci). Dengan penilaian yang tidak terperinci tersebut, dikhawatirkan akan adanya penilaian yang bersifat subjektif (berdasarkan kepentingan pribadi), dapat menimbulkan kecemburuan sosial bagi guru yang belum menerima rekomendasi. Untuk mengatasi permasalahan tersebut maka dirancang sebuah sistem pendukung keputusan menggunakan Metode Simple Additive Weighting. Adapun dalam penelitian ini menggunakan 14 kriteria. Dalam penelitian ini aplikasi menggunakan bahasa pemrograman PHP, sedangkan basisdata nya menggunakan MySQL. Hasil akhir dari penelitian ini didapatkan bahwa sistem pendukung keputusan dengan metode SAW mampu mengatasi permasalahan dalam melakukan penilaian kinerja guru kelas.
\end{abstract}

Kata Kunci - MySQL, Penilaian Kinerja Guru Kelas, PHP, SAW.

\section{PENDAHULUAN}

Guru adalah pendidik profesional dengan tugas utama mendidik, mengajar, membimbing, mengarahkan, melatih, menilai dan mengevaluasi peserta didik pada pendidikan anak usia dini melalui jalur formal pendidikan dasar dan pendidikan menengah. Kualitas pengajaran dan standar akademik perlu dievaluasi dan ditingkatkan karena pendidikan sangat penting untuk kita semua. Menurut peraturan menteri negara pendayagunaan aparatur negara dan reformasi birokrasi nomor 16 tahun 2009. Penilaian kinerja guru adalah penilaian dari tiap butir kegiatan tugas utama guru dalam rangka pembinaan karir, kepangkatan, dan jabatan.

Sekolah Dasar Negeri Kampung Dalem 3, Sekolah Dasar Negeri Kampung Dalem 4 dan Sekolah Dasar Negeri Kampung Dalem 5 Kediri melakukan secara rutin penilaian kinerja guru terhadap seluruh guru kelas. Proses penilaian kinerja guru di Sekolah Dasar Negeri Kampung Dalem 3, Sekolah Dasar Negeri Kampung Dalem 4 dan Sekolah Dasar Negeri Kampung Dalem 5 masih munggunakan sistem manual dan belum terperinci. Masalah yang terjadi dalam proses evaluasi penilaian kinerja guru diantaranya adalah subyektifitas pengambilan keputusan akan terasa, terutama jika beberapa guru yang ada memiliki kemampuan, nilai dan beberapa pertimbangan lain yang tidak jauh berbeda. Dalam pembahasan ini diharapkan memberikan suatu solusi dengan merancang sistem pendukung keputusan penilaian kinerja guru yang dikomputerisasikan berdasarkan sistem manual yang telah berjalan pada Sekolah Dasar 
Negeri Kampung Dalem 3, Sekolah Dasar Negeri Kampung Dalem 4 dan Sekolah Dasar Negeri Kampung Dalem 5 kediri. Metode yang digunakan adalah metode Simple Additive Weighting (SAW). Metode dipilih karena metode ini menentukan nilai bobot untuk setiap kriteria, kemudian dilanjutkan dengan proses perankingan yang akan menyeleksi alternatif terbaik dari beberapa alternatif.

Beberapa jurnal yang menjadi referensi dalam penelitian ini, Penelitian yang di lakukan oleh [1] dengan judul "Sistem Pendukung Keputusan Penilaian Kinerja Guru (PKG) Menggunakan Metode Simple Additive Weighting (SAW) SMA Negeri 9 Semarang". Pada jurnal ini, Kriteria yang dipakai untuk kinerja guru ada 6 yaitu Kesetiaan, Prestasi Kerja, Tanggung Jawab, Ketaatan, Kejujuran dan Kerjasama. Penelitian yang lain di lakukan oleh [2] dengan judul "Sistem Pendukung Keputusan Pemilihan Guru Terbaik Pada Smk Maria Goretti Pematangsiantar Menggunakan Metode Simple Additive Weighting (SAW)". Pada jurnal ini, kriteria yang dipakai untuk kinerja guru ada 5 kriteria.

\section{METODE PENELITIAN}

\subsection{Metode Pengumpulan Data}

Metode pengumpulan data untuk 2urvey pendukung keputusan penilain kinerja guru kelas Menggunakan Metode Simple Additive Weighting antara lain 2urvey, wawancara dan studi pustaka [3]. Survei teknik pengumpulan data secara langsung dengan cara terjun langsung di tempat penelitian yang dipilih yaitu di SDN Kampung Dalem 3, SDN Kampung Dalem 4, SDN Kampung Dalem 5. Wawancara Mengadakan wawancara dengan pihak Sekolah Dasar Negeri Kampung Dalem 3, Sekolah Dasar Negeri Kampung Dalem 4 dan Sekolah Dasar Negeri Kampung Dalem 5 mengenai masalah yang dihadapi dalam penilaian kinerja guru.

Studi Pustaka adalah teknik pengumpulan data untuk mendapatkan data-data yang bersifat teoritis maka penulis melakukan pengumpulan data dengan cara membaca dan mempelajari buku-buku, jurnal, makalah, internet ataupun referensi lain yang berhubungan dengan masalah pembahasan.

\subsection{Analisis Data}

\section{A. Metode Simple Additive Weighting}

Metode Simple Additive Weighting (SAW) sering juga dikenal istilah metode penjumlahan terbobot. Salah satu metode yang digunakan untuk menyelesaikan masalah dari Multi-Attribute Decision Making (MADM). Metode Simple Additive Weighting (SAW) metode yang digunakan untuk mencari alternatif optimal dari sejumlah alternatif dengan kriteria tertentu. Metode Simple Additive Weighting (SAW) membutuhkan proses normalisasi matriks keputusan $\mathrm{X}$ ke suatu skala yang dapat diperbandingkan dengan semua rating alternatif yang ada [4]. Langkah - langkah Perhitungan Simple Additive Weighting

Penyelesaian Metode Simple Additive Weighting [4] Adalah sebagai berikut :

- Menentukan kriteria - kriteria yang akan digunakan dalam pengambilan keputusan.

- Menentukan rating kecocokan setiap alternatif pada setiap kriteria.

- Menghitung Normalisasi, Formula untuk melakukan normalisasi tersebut adalah sebagai berikut: 


$$
r_{i j} \begin{cases}\frac{x_{i j}}{\max _{i} x_{i j}} & \text { Jika } \mathrm{j} \text { adalah atribut keuntungan ( benefit ) } \\ \frac{\min _{i} x_{i j}}{x_{i j}} & \text { Jika j adalah atribut biaya ( cost) }\end{cases}
$$

- Menentukan nilai prefensi untuk setiap alternatif (Vi) dengan cara menjumlahkan hasil kali antara matriks ternormalisasi dengan nilai bobot. Jika nilai Vi lebih besar maka alternatif Ai lebih terpilih. Berikut rumus nilai preferensi setiap alternative (Vi) diberikan sebagai :

$$
\mathrm{V}_{\mathrm{i}}=\sum_{j=1}^{n} \mathrm{w}_{\mathrm{j}} \mathrm{r}_{\mathrm{ij}}
$$

\subsection{Perancangan Sistem}

Perancangan sistem pendukung keputusan penilaian kinerja guru kelas ini dimulai dengan pembuatan Context Diagram, pembuatan Data Flow Diagram (DFD) dan dibuat dengan bahasa Pemrograman PHP dengan database menggunakan MySQL.

A. Context Diagram

Diagram konteks atau Context Diagram adalah diagram yang terdiri dari suatu proses dan menggambarkan ruang lingkup suatu sistem. Diagram konteks merupakan level tertinggi dari DFD yang menggambarkan seluruh input ke sistem atau output dari sistem. Ia akan memberi gambaran tentang keseluruan sistem [5]. Tools yang digunakan untuk membuat Context Diagram menggunakan Power Designer.

B. Data Flow Diagram (DFD)

DFD sering digunakan untuk menggambarkan suatu sistem yang telah ada atau sistem baru yang akan dikembangkan secara logika tanpa mempertimbangkan lingkungan fisik dimana data tersebut mengalir (misalnya lewat telepon, surat dan sebagainya) atau lingkungan fisik dimana data tersebut akan disimpan (misalnya file kartu, microfiche, hard disk, tape, diskette dll) [5]. Tools yang digunakan untuk membuat data flow diagram menggunakan Power Designer.

\section{HASIL DAN PEMBAHASAN}

\subsection{Pengumpulan Data}

Data yang akan digunakan dalam penilaian kinerja guru kelas menggunakan 50 data, dari data guru SDN Kampung Dalem 3 ada 16 guru, SDN Kampung Dalem 4 ada 16 guru dan SDN Kampung Dalem 5 ada 18 guru.

\subsection{Analisis Data}

Dari 50 data guru akan dinilai menggunakan 14 kriteria penilaian kinerja guru kelas, 14 kriteria dapat dilihat pada Tabel 1.

\begin{tabular}{|c|c|c|c|}
\hline Att & Kriteria & & Bobot \\
\hline $\mathrm{C} 1$ & $\begin{array}{l}\text { Menguasai Karakteristik } \\
\text { Didik. }\end{array}$ & Peserta & 10 \\
\hline $\mathrm{C} 2$ & $\begin{array}{l}\text { Mengusai Teori Belajar Da } \\
\text { Prinsip } \\
\text { Mendidik. }\end{array}$ & $\begin{array}{l}\text { Prinsip- } \\
\text { Yang }\end{array}$ & 10 \\
\hline
\end{tabular}

Tabel 1. Kriteria 


\begin{tabular}{|c|l|c|}
\hline Att & \multicolumn{1}{|c|}{ Kriteria } & Bobot \\
\hline C3 & Pengembangan Kurikulum. & 9 \\
\hline C4 & $\begin{array}{l}\text { Kegiatan Pembelajaran Yang } \\
\text { Mendidik. }\end{array}$ & 9 \\
\hline C5 & $\begin{array}{l}\text { Pengembangan Potensi Peserta } \\
\text { Didik. }\end{array}$ & 8 \\
\hline C6 & Komunikasi Dengan Peserta Didik. & 8 \\
\hline C7 & $\begin{array}{l}\text { Penilaian Dan Evaluasi. } \\
\text { C8 }\end{array}$ & $\begin{array}{l}\text { Bertindak Sesuai Dengan Norma } \\
\text { Agama, Hukum, Sosial Dan Sosial } \\
\text { Budaya. }\end{array}$ \\
\hline C9 & $\begin{array}{l}\text { Menunjukan Pribadi Yang Dewasa } \\
\text { Dan Teladan. }\end{array}$ & 7 \\
\hline C10 & $\begin{array}{l}\text { Etos Kerja, Tanggung Jawab Yang } \\
\text { Tinggi dan Rasa Bangga Menjadi } \\
\text { Guru. }\end{array}$ & 6 \\
\hline C11 & $\begin{array}{l}\text { Bersikap Inklusif, Bertindak } \\
\text { Obyektif, Serta Tidak Diskriminatif. }\end{array}$ & 5 \\
\hline C12 & $\begin{array}{l}\text { Komunikasi Dengan Sesama Guru, } \\
\text { Tenaga Kependidikan, Orang Tua, } \\
\text { Peserta Didik Dan Masyarakat. }\end{array}$ & 5 \\
\hline C13 & $\begin{array}{l}\text { Penguasaan Materi, Struktur, } \\
\text { Konsep Dan Pola Pikir Keilmuan } \\
\text { Yang Mendukung Matapelajaran } \\
\text { Yang Diampu. }\end{array}$ \\
\hline C14 & $\begin{array}{l}\text { Mengembangkan Keprofesionalan } \\
\text { Melalui Tindakan Yang Reflektif. }\end{array}$ & 5 \\
\hline
\end{tabular}

Dari 14 kriteria utama tersebut masing-masing kriteria utama memiliki sub-sub kriteria yang sama dapat dilihat pada Tabel 2.

Tabel 2. Sub Kriteria

\begin{tabular}{|c|c|}
\hline Nama & Nilai \\
\hline $\begin{array}{c}\text { Tidak } \\
\text { Terpenuhi }\end{array}$ & 1 \\
\hline Cukup & 2 \\
\hline Terpenuhi & 3 \\
\hline $\begin{array}{c}\text { Sangat } \\
\text { Terpenuhi }\end{array}$ & 4 \\
\hline
\end{tabular}

Dari 50 data guru yang di uji menggunakan metode Simple Additive Weighting akan di ambil 3 garu dengan nilai terbaik yang akan mendapatkan rekomendasi kenaikan golongan / pangkat, dapat dilihat pada Tabel 3. 
Tabel 3. Hasil Perhitungan

\begin{tabular}{|c|c|c|}
\hline No & Alternatif & Hasil \\
\hline 1 & A1 & 84.42 \\
\hline 2 & A2 & 83.67 \\
\hline 3 & A3 & 83.25 \\
\hline 4 & A4 & 81.42 \\
\hline 5 & A5 & 81.17 \\
\hline 6 & A6 & 81.00 \\
\hline 7 & A7 & 80.83 \\
\hline 8 & A8 & 80.75 \\
\hline 9 & A9 & 80.17 \\
\hline 10 & A10 & 79.75 \\
\hline
\end{tabular}

Hasil perhitungan 50 data guru menggunakan metode Simple Additive Weighting di dapat alternatif A1, A2 dan A3 mendapatkan nilai tertinggi. Dengan rincian nilai kriteria dapat dilihat pada Tabel 4.

Tabel 4. Rating Kecocokan

\begin{tabular}{|c|c|c|c|c|c|c|c|c|c|c|c|c|c|c|c|}
\hline \multirow{3}{*}{ No } & \multirow{3}{*}{ Alternatif } & \multicolumn{14}{|c|}{ Kriteria } \\
\hline & & $\mathrm{C}$ & $\mathrm{C}$ & $\mathrm{C}$ & $\mathrm{C}$ & $\mathrm{C}$ & $\mathrm{C}$ & $\mathrm{C}$ & $\mathrm{C}$ & $\mathrm{C}$ & $\mathrm{C}$ & $\mathrm{C}$ & $\mathrm{C}$ & $\mathrm{C}$ & $\mathrm{C}$ \\
\hline & & 1 & 2 & 3 & 4 & 5 & & & & 9 & & 11 & & & 14 \\
\hline 1 & A1 & 2 & 3 & 3 & 4 & 3 & 4 & 4 & 4 & 2 & 4 & 3 & 2 & 4 & 3 \\
\hline 2 & A2 & 3 & 3 & 2 & 3 & 4 & 2 & 3 & 3 & 4 & 4 & 3 & 4 & 4 & 3 \\
\hline 3 & A3 & 2 & 3 & 4 & 3 & 4 & 3 & 2 & 4 & 4 & 3 & 4 & 3 & 2 & 4 \\
\hline 4 & A4 & 3 & 3 & 3 & 4 & 2 & 4 & 3 & 3 & 2 & 4 & 3 & 2 & 4 & 2 \\
\hline 5 & A5 & 2 & 3 & 3 & 3 & 3 & 3 & 4 & 3 & 4 & 4 & 3 & 3 & 3 & 2 \\
\hline 6 & A6 & 3 & 3 & 2 & 4 & 3 & 3 & 2 & 3 & 3 & 3 & 4 & 4 & 3 & 3 \\
\hline 7 & A7 & 2 & 3 & 2 & 3 & 4 & 3 & 4 & 4 & 3 & 4 & 3 & 3 & 4 & 2 \\
\hline 8 & A8 & 2 & 2 & 3 & 4 & 3 & 4 & 4 & 3 & 3 & 4 & 3 & 3 & 4 & 2 \\
\hline 9 & A9 & 3 & 3 & 2 & 3 & 4 & 3 & 2 & 3 & 4 & 4 & 2 & 2 & 3 & 4 \\
\hline 10 & A10 & 2 & 3 & 3 & 3 & 4 & 2 & 4 & 3 & 4 & 3 & 2 & 4 & 3 & 4 \\
\hline
\end{tabular}

Seterusnya sampai alternatif ke 50 .

\subsection{Perancangan Sistem}

\section{A. Context Diagram}

Pada gambar 1 adalah diagram konteks tentang Sistem Pendukung Keputusan Penilaian Kinerja Guru Kelas di Sekolah Dasar Negeri Kampung Dalem : 


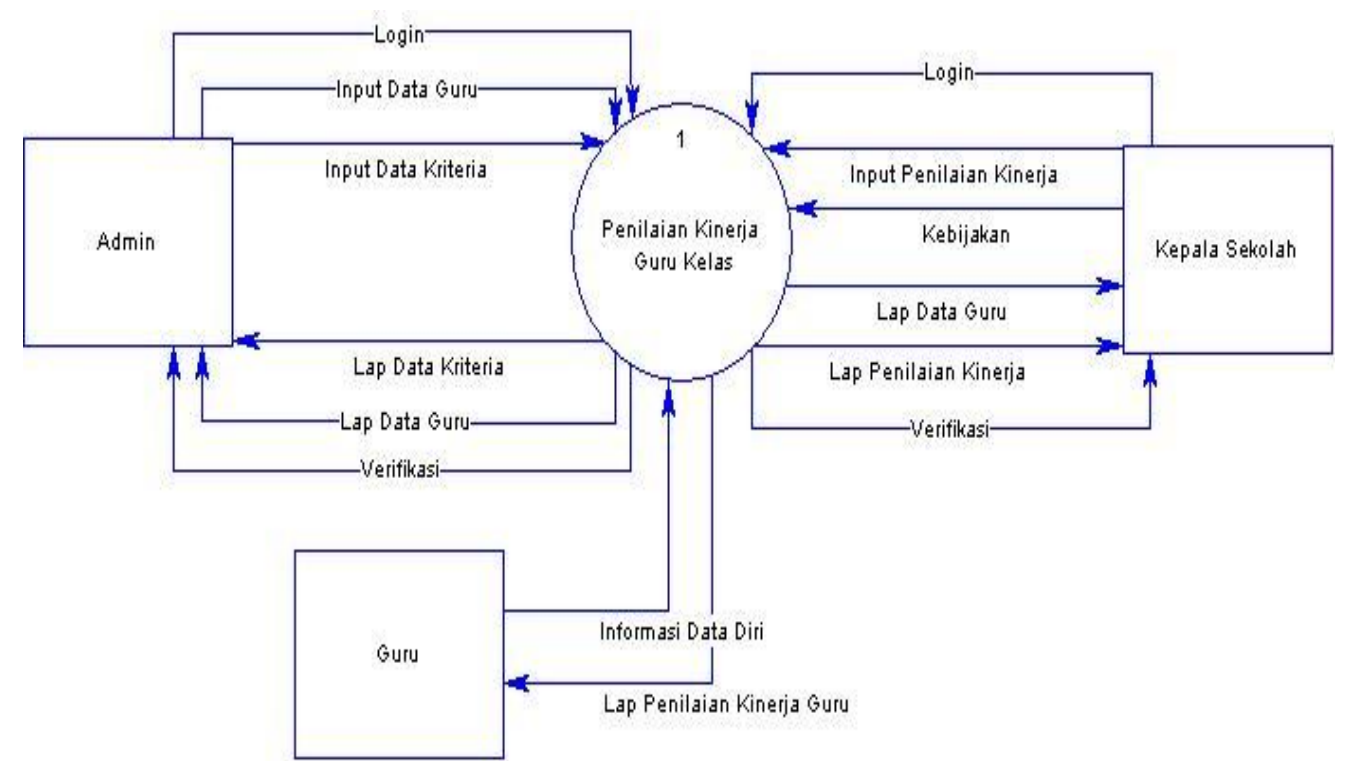

Gambar 1. Context Diagram

Pada Gambar 1. Context Diagram diatas, sistem pendukung keputusan penilaian kinerja guru kelas berhubungan dengan tiga entity yaitu admin, kepala sekolah dan guru. Admin melakukan login dan melakukan input data kriteria, data guru dan mendapat laporan data kriteria, laporan data guru. Guru memberikan informasi data guru dan mendapat laporan peniliaian kinerja guru. Kepala sekolah melakukan login dan melakukan input nilai kinerja guru dan mendapat loparan penilaian kinerja guru dan data guru.

\section{B. Data Flow Diagram Level}

Gambar 2 adalah bentuk Data Flow Diagram (DFD) Level 0 tentang Sistem Pendukung Keputusan Penilaian Kinerja Guru Kelas di Sekolah Dasar Negeri Kampung Dalem : 


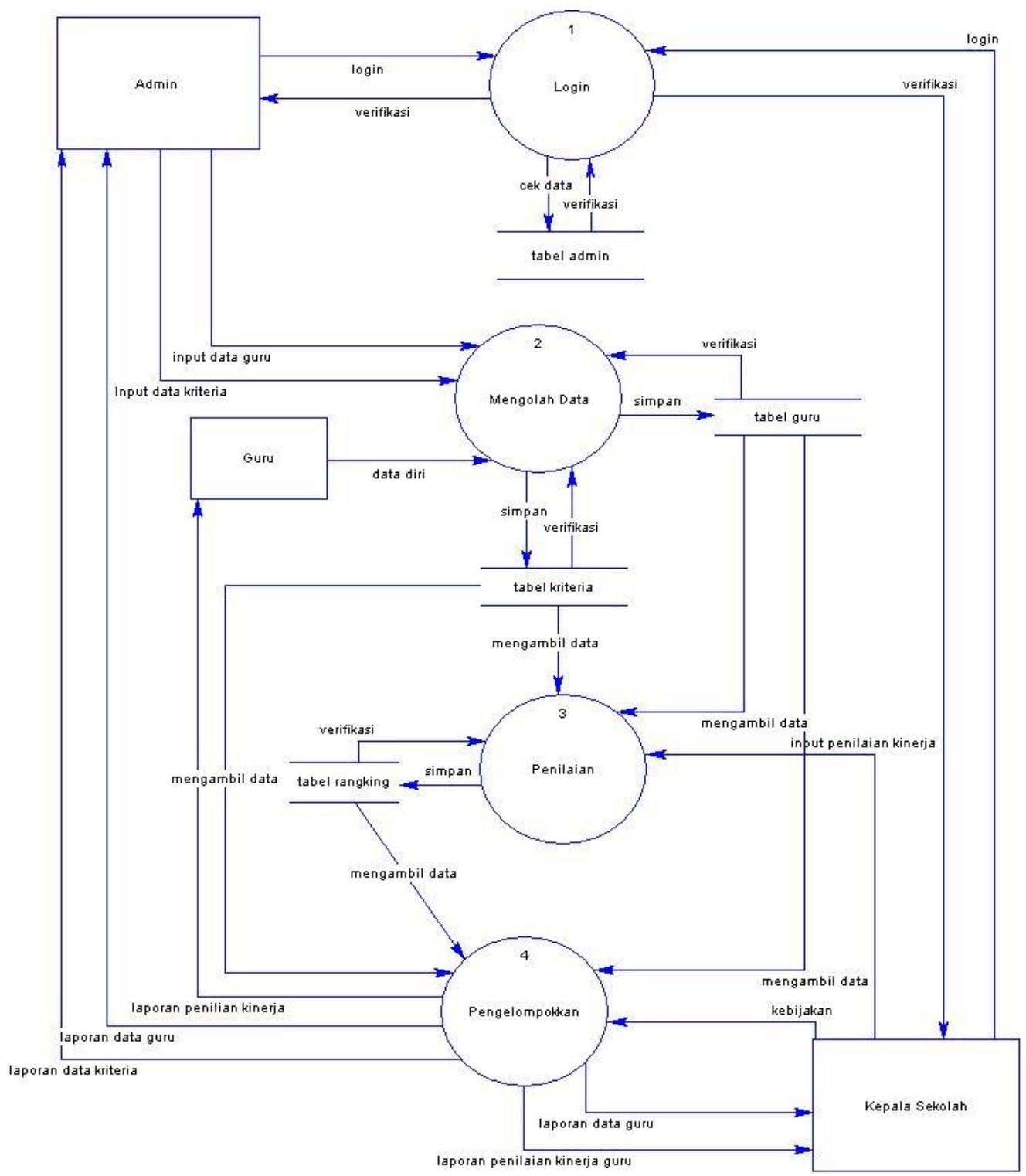

Gambar 2. Data Flow Diagram

Pada Gambar 2. Data Flow Diagram adalah sebagai berikut :

- Proses 1, Admin dan Kepala Sekolah harus login terlebih dahulu dan mendapat verifikasi login.

- Proses 2, Guru memberikan informasi data diri dan Admin menginputkan data guru.

- Proses 3, Hasil dari penginputan data pada proses 2 admin menginputkan kriteria dan kepala sekolah menginputkan penilaian kinerja yang akan disimpan di tabel rangking.

- Proses 4, Dari tabel guru, tabel kriteria dan tabel rangking di kelompokkan menjadi laporan dan akan di teruskan kepada guru, admin dan kepala sekolah.

\subsection{Antar Muka Pengguna}

a. Halaman Data Guru 
Halaman data guru digunakan oleh admin untuk melihat, menginputkan, edit data dan hapus data guru.

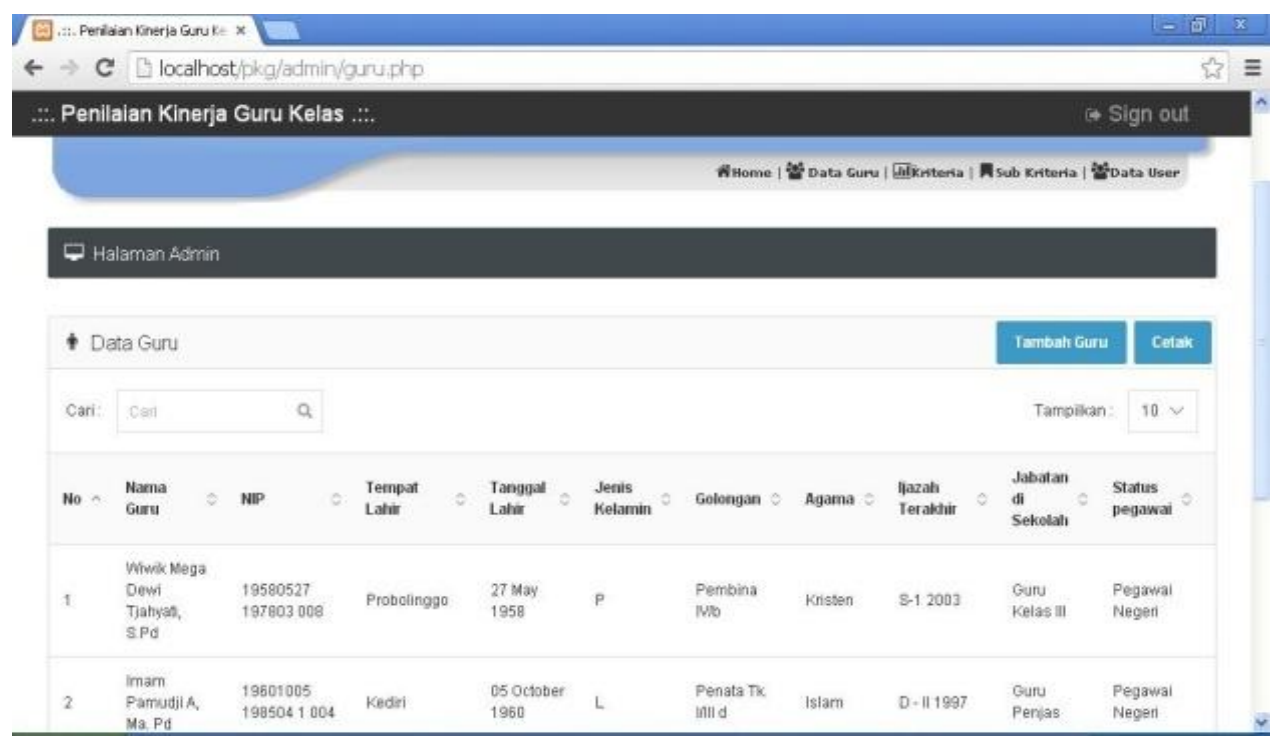

Gambar 3. Halaman Data Guru

b. Halaman Data Kriteria

Halaman data kriteria digunakan admin untuk melihat data kriteria, input, edit dan hapus data kriteria.

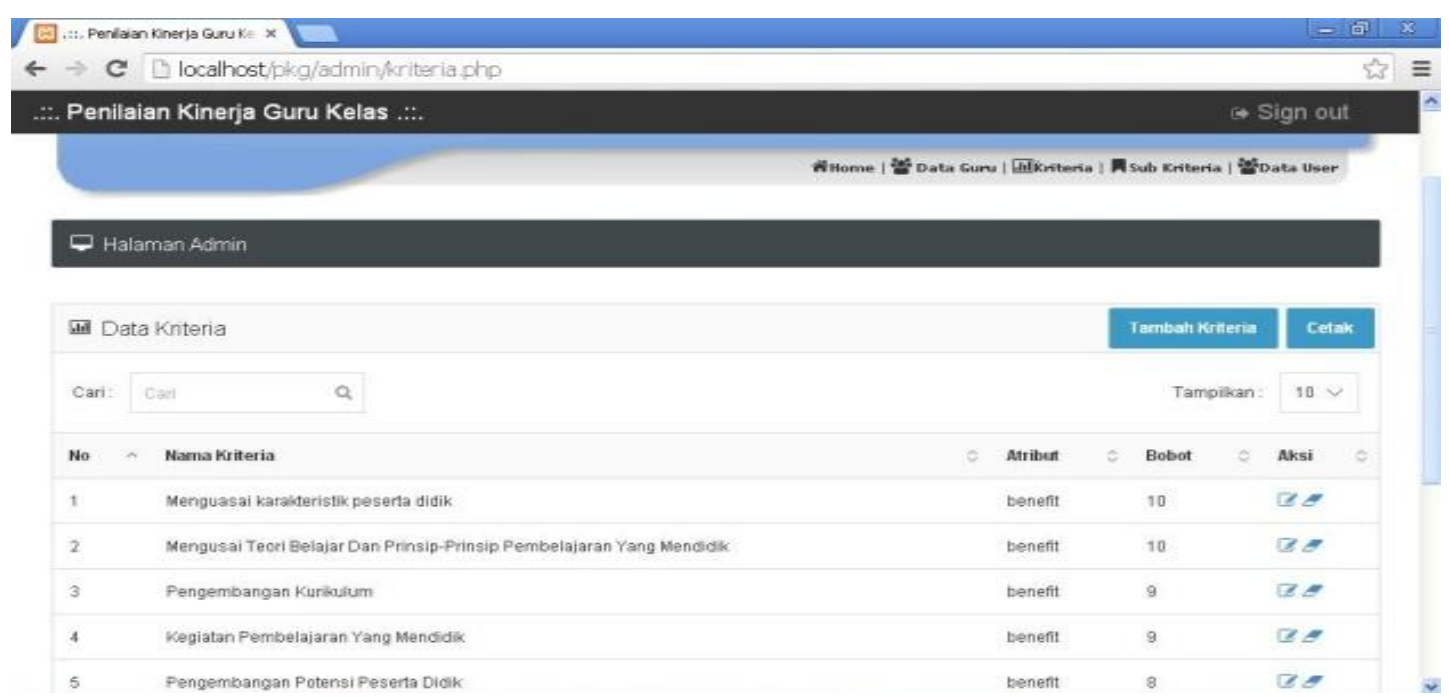

Gambar 4. Halaman Data Kriteria

c. Halaman Data Sub Kriteria

Halaman data sub kriteria digunakan admin untuk melihat data sub kriteria, input, edit dan hapus data kriteria. 


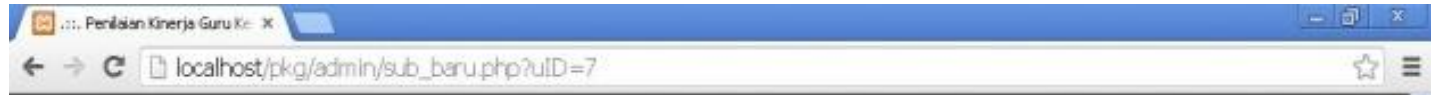

$\leftarrow \rightarrow$ C [ localhost/pkg/adimin/sub_beruphp?uID=7

\section{† Halaman Admin}

In Data Sub Kriteria Menguasai karakteristik peserta didik

a

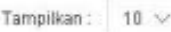

No $\quad$ Nama Sub Kuiteria

Keterangan

Bebot

Tidak tempenuki

Cukup

Tidak terpenuhi

Cusup

Terpenuhi

Sangat Terpenuhi

Terpenuhi

Sangat terpenuki

Aksi

[1]

(3)

ए8

18

1 : Akhir

d. Halaman Penilaian

Gambar 5. Halaman Data Sub Kriteria

Form penilaian digunakan kepala sekolah untuk menginputkan penilaian dan menghapus penilaian setiap guru.

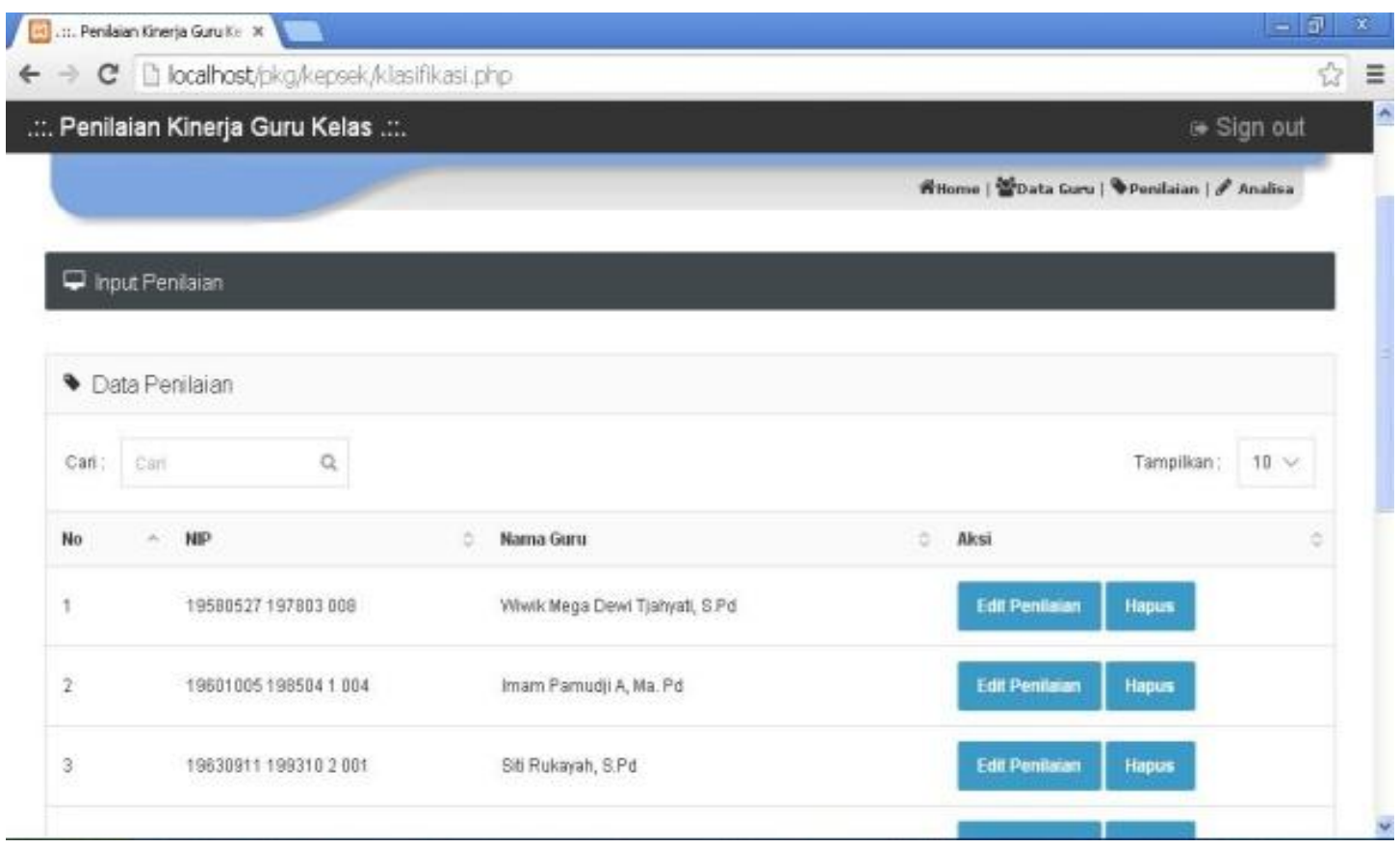

Gambar 6. Halaman penilaian

e. Halaman Analisa

Halaman Analisa digunakan kepala sekolah untuk melihat hasil penilaian kinerja guru. 


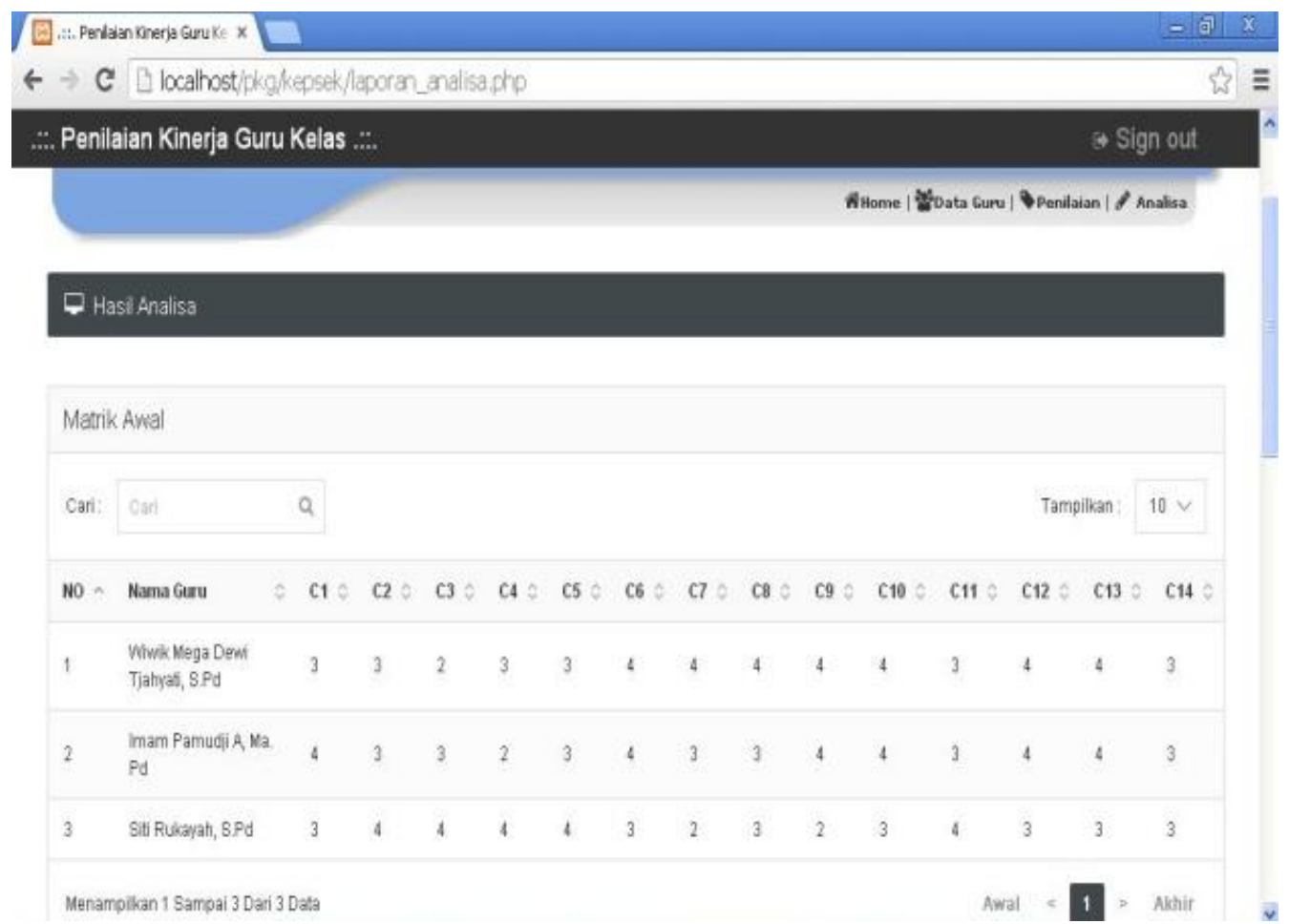

Gambar 7. Halaman Analisis

\section{KESIMPULAN}

Berdasarkan pembahasan implementasi dan evaluasi dari bab-bab sebelumnya serta teori yang ada, maka dapat ditarik kesimpulan. Sistem pendukung keputusan penilaian kinerja guru kelas menggunakan metode SAW berbasis PHP selesai dibuat, dan dapat diterapkan dalam menghitung penilaian kinerja guru untuk mencari alternatif terbaik yang akan mendapatkan rekomendasi kenaikan golongan pada SDN Kampung Dalem. Sistem pendukung keputusan penilaian kinerja guru kelas menggunakan metode SAW pada SDN Kampung Dalem telah menunjukkan hasil Akhir penilaian kinerja guru. Penambahan data guru, data kriteria, data sub kriteria sudah dapat dilakukan dan tersimpan dalam database. Berdasarkan penelitian yang dilakukan, masih ada beberapa kekurangan yang terdapat dalam aplikasi sistem tersebut yang perlu dibenahi, untuk itu diberikan saran kepada pihak yang memakai dan pengembang aplikasi berikutnya. Saran yang diberikan oleh penulis untuk pengembangan para peneliti selanjutnya yaitu:

Sistem ini agar di kembangkan bukan hanya digunakan dalam penilaian kinerja guru kelas tapi bisa untuk penilaian kinerja guru mata pelajaran. Diharapkan dapat mengembangkan program yang telah dibuat ini menjadi suatu sistem on-line dan dapat digunakan untuk sekolah lain dalam menghitung penilaian kinerja guru.

\section{DAFTAR PUSTAKA}

[1] Sutojo, T., 2013, Sistem Pendukung Keputusan Penilaian Kinerja Guru (PKG) Menggunakan Metode Additive Weighting (SAW) SMA Negeri 9 Semarang, Semarang : Universitas Dian Nuswantoro.

[2] Solikhun, 2016, Sistem Pendukung Keputusan Pemilihan Guru Terbaik Pada Smk Maria Goretti Pematangsiantar Menggunakan Metode Simple Additive 
Weighting (Saw) (Studi Kasus : Smk Maria Goretti Pematangsiantar), Vol. 1, No. 1, hal. 2527-5771.

[3] Turban, Efraim, 2015 , Decision Support Systems and Intelligent Systems Yogyakarta: Andi Offset.

[4] Kusumadewi, S., Hartati, S., Harjoko, A., Wardoyo, R., 2006. Fuzzy MultipleAttribute Decision Making. Yogyakarta: Graha Ilmu.

[5] Jogiyanto, 2010, Analisis dan Desain Sistem Informasi. Edisi IV. Yogyakarta :Andi Offset. 